\title{
SCHOOL LEADERSHIP AND MANAGEMENT IN SOUTH AFRICA: FINDINGS FROM A SYSTEMATIC LITERATURE REVIEW
}

\section{Introduction}

South Africa celebrated twenty years of democracy in 2014 and this seems to provide a good opportunity to review the progress made in developing an integrated education system, to replace the previous racially stratified system. The key legislation introducing a unified system was the 1996 South African Schools Act (SASA). The SASA gave considerable attention to school leadership and management, recognising their importance in developing a fully functional system, which would improve school and learners' outcomes.

As part of a wider strategy to improve the education system, the South African Department of Basic Education (DBE) introduced an Advanced Certificate in Education (School Leadership) from 2007. The DBE is now planning to introduce an enhanced qualification for principals, an Advanced Diploma in Education (School Leadership and Management). The $\mathrm{DBE}^{1}$ commissioned the authors to produce a systematic literature review, funded by the Zenex Foundation, to underpin the design and content of the ADE.

The broad aim of the literature review was to establish what research has been conducted, and what literature has been published, on school leadership and management in South Africa since 2007, when a similar review was prepared (author and author 2007). This systematic review includes identification of all relevant articles in South African and international journals, books, chapters in edited volumes, theses, and published research reports. This paper reports on the outcome of this review and also includes several recent sources examined since preparing the previous review.

Methodology

The literature research was conducted using electronic database searching, hand searching of key journals, searching of specialist websites, and using general search engines on the internet such as 'Google' and 'Google scholar'. The databases included Swetsnet, Eric, British Educational Index, JStor and several journal archives. A total of 523 references were considered by reading the abstracts. Fine-grained selection identified 162 articles and reports which were considered in greater detail and form the basis of this review.

\footnotetext{
${ }^{1}$ The views expressed in this paper are those of the authors, not the DBE or the Zenex Foundation
} 
The criteria for inclusion were that the papers focused centrally on leadership or management in the South African schools' context. The abstracts were assessed against this general criterion and also to establish whether and how they fitted the structure of the ACE programme. More specific criteria for inclusion were:

Material based on leadership practice.

Using empirical sources wherever possible and avoiding normative material.

Avoiding purely descriptive material and drawing on papers which offered reflection, conceptual development and examples to inform policy and practice.

Material that relates practice in South Africa to conceptual frameworks developed in other (predominantly Western) contexts.

The overarching question informing the review was "what new research and insights on school leadership and management have been published since the previous review in 2007'. The prime purpose was practical, rather than theoretical, but conceptual issues are explored where they inform the research and literature reviewed. The findings are structured in line with the framework developed for the South African ACE programme, in order to facilitate the design and content of the planned ADE programme, as follows:

The South African policy context

The role of the school principal

School culture

Leadership and management models

School governance

Accountability

School development

Leading and managing people, including staff development, mentoring, performance management, leadership teams, teacher unions and leadership development Managing financial and physical resources

Managing teaching and learning, including curriculum management, evaluating learner outcomes, monitoring classroom practice, classroom observation, mentoring and modeling.

The South African Policy Context 
Context is regarded as increasingly significant for school leadership (Bush 2011). In South Africa, the transition from a racially stratified education system to unified non-racist provision has dramatically changed the policy context for school leaders and managers. The impact of legislation since 1994 is summed up by Ngcobo and Tikly (2008: 1):

'The government has instigated wide-ranging initiatives to transform education from its apartheid past . . . However, despite years of reform effort, South Africa continues to lag behind in international comparisons and has failed to significantly raise the performance of historically disadvantaged learners'.

The reasons for the limited impact of reform initiatives are manifold and complex. They include continuing problems of deeply entrenched class and racial attitudes stemming from the apartheid period (Soudien, 2007), chronic lack of physical and human resources (Jansen, 2005), educator under-training and under-development, and perceived school governing body ineptitude (Jansen, 2005). Progress has also been hampered by wider socio-economic problems, notably the impact of HIV/AIDS, parental breakdown, poverty, and local vandalism, petty crime and disrespect (Kamper, 2008; Ngcobo and Tikly, 2010, Jacobs 2014). There has been some improvement, as reflected in the evaluation of the Quality Learning Project (Kanjee and Prinsloo, 2005), the evaluation of the ACE: School Leadership (Bush and Glover 2012) and in enhanced leadership for teaching and learning (Hoadley et al, 2009). However, many schools continue to provide inadequate education for their learners, judging by school leaving examination (matric) results and primary school annual national assessment (ANA) outcomes (Wolhuter 2014).

Ngcobo and Tikly (2008: 5) also point to the influence of ethnic identities and values, complicated by the fluidity of learner populations, especially in urban schools:

'This is compounded by migratory labour which finds rural values continually enmeshing with the urban. Rather than deal with a uniform set of values, this means leaders must deal with sometimes quite differing sub-cultures and values held by different groups within the local community and the school that constitute something of a 'moving target'.

The great diversity of school contexts in South Africa, as a consequence of Apartheid-era policies and differential funding, make generalisations unwise. Schools in the big cities compare favourably with those in many Western countries. However, schools in townships, rural areas and informal settlements continue to experience a range of problems, including inadequate infrastructure, under-trained and demotivated educators, low expectations and 
poor post-school employment prospects. Despite these differences, however, the context for school leadership is also strongly influenced by legislation and policy, notably the South African Schools Act (1996).

\section{The role of the school principal}

The changing context for leadership has been accompanied by changes in the roles of school principals. This is manifested partly through professionalising the principalship (Van der Westhuizen and van Vuren 2007) and partly by an emphasis on developing a shared vision (Ngcobo and Tikly 2010). The principal's role also includes ensuring the best possible resource achievement, allocation and evaluation, and the security of the site and property. Xaba (2012) adds that such processes are required to ensure that teaching and learning are of high quality, whatever the context. As we shall see later, this links to the growing attention to instructional leadership, and the effective use of all educators through distributed leadership.

\section{$\underline{\text { School culture }}$}

The transformation of the policy context, and the changing demography of learners and educators, has profound implications for school culture (Zulu 2004; Villiers and Pretorious 2011). Nieman and Kotze's (2006: 614) survey of 30 school staff in the Free State led them to conclude that school culture is characterised by sociability (friendship and morale) and solidarity (collective will and mutual interest). They also note the links between culture and leadership:

'Organisational culture [is] cultivated by management and, therefore, it would be a true asset to a school if a suitable principal could be appointed: a principal who leads in such a way that a culture, in which teaching and learning could thrive, is established' (p.622)

Barnes et al (2012: 73) undertook a similar investigation in the Eastern Cape. Their findings show a clear link between enhanced school culture and climate, and lower levels of violence. Understanding this relationship made it possible for school leaders to institute positive action to recognise culture and climate as a means of securing safer schools.

Vos et al $(2012,2013)$ consider the way in which culture is reflected in educators' attitudes to their working environment in primary schools in North-West province. Their findings, based 
on a survey of 904 teachers in 68 schools, indicate that educators are not only determinants of culture but are affected by it. They conclude with certain normative statements about educator behaviour:

'The educators' involvement and cooperation in school activities should be set as a requisite in order to reach common objectives. Negative or destructive actions, comments, and negative criticism, should not be tolerated'. (Vos et al 2012: 67)

The role of the principal in developing a culture of teaching and learning is discussed by Bush (2013: 14), who comments that:

'Changing school culture has to be a deliberate process, intended to achieve specific results, such as enhanced learner outcomes. Culture is usually deeply embedded and is difficult to shift particularly if, as in most South African schools, most educators have substantial experience in the same school and are used to working in a certain way. It often takes an external stimulus or threat to produce new patterns of working'.

Weeks (2012: 9), following an extensive literature review, argues that the dysfunctionality of so many schools in South Africa requires a 'quest for learning', involving both learners and educators, and building upon their cultural heritage as follows to establish a learning community within the classroom'

Christie et al (2007: 60) carried out a literature review, and also conducted an enquiry with 18 middle ranking schools. Their research showed that all these schools had organisational cultures or mindsets that supported a work ethic, expected achievement, and acknowledged success, leading to a sense of purpose, commitment, achievement, acknowledged success, and an enabling work ethic' (Ibid: 5).

\section{Leadership and management models}

Bush's (2011) well known typology identifies six management and ten leadership models. Three of these models (transformational, instructional and distributed) have a particular resonance in the South African literature and these are among the approaches discussed below.

Transformational leadership 
Transformational leaders succeed in gaining the commitment of educators through building school vision, establishing school goals, modelling best practices, and demonstrating high performance expectations (Bush 2011, Leithwood 1994, Steyn 2013). In South Africa, there is extensive use of transformational language in the post-Apartheid policy discourse but only limited evidence of its impact in schools.

Singh and Lokotsch (2005: 286), drawing on interviews with educators in two urban primary schools, discuss the understanding and reality of transformational leadership in South Africa, and comment that:

'The transformational approach must respond to needs amongst followers and must look for motives, extrinsic and intrinsic, to satisfy those needs by enhancing opportunities, empowering people, giving more freedom, performance evaluation and the full support of the leader . . . The education system of past years has made it very difficult to change because of the comfort zone of bureaucratic structures'.

Moorosi (2010: 560), drawing from her research in KZN, argues that transformation should include changes in community attitudes to women:

'The interplay between the social and organizational levels becomes stark where the social norms and beliefs appear to be informing what happens in the school context. This perpetuates the reproduction of a continued male domination in the management of a field occupied mostly by women:

Msila's (2011: 447) research with 56 managers of under-performing schools in the Eastern Cape makes an important link between transformational and instructional leadership:

'Many participants . . . realise that understanding of context is crucial in improving school management and leadership strategies. For example, it matters whether a principal chooses to be an instructional leader or a transformational leader'.

Instructional leadership

As noted above, Msila (2011: 447) claims that leaders should make conscious decisions to operate within a particular framework; instructional or transformational. There is increasing recognition that instructional leadership may be an appropriate approach to school 
improvement in South Africa. However, Bush (2013) adds that little attention has been given to the processes by which improvement can be achieved, including the need for modelling, monitoring and professional dialogue. These may be manifested through high quality observation of classrooms, discussion of practice within learning areas or phases, and the achievement of consistency in expectations of behaviour and practice for both learners and educators.

Middle managers are also responsible for instructional leadership and Ali and Botha (2006), in the first major study of HoDs in South Africa, focused on 100 secondary school HoDs in Gauteng. In their literature review, they record that HoDs have the main responsibility for curriculum 'delivery'. They also note that, if teaching and learning are to improve significantly, 'HoDs will have to spend much more time in supervising the teaching and learning activities that occur daily in their subject or learning area' (p.17). Significantly, 79\% of their respondents refer to 'monitoring the teaching and learning standards of educators and learners' as one of their major contributions to school improvement (p.80), but the authors question whether the HoDs are really carrying out this task. They also suggest that middle managers should develop a routine of analysis of results, planning for improvement, monitoring classroom practice, using observation and target setting.

These points are similar to the recommendations made by Bush et al (2010) in their study of MTL in the Limpopo and Mpumalanga provinces. Their suggestions are that HoDs should:

- Hold regular meetings of the educator team to plan teaching and to discuss problems.

- Model good practice by taking lessons while educators observe.

- Observe educators regularly and provide structured and constructive feedback to enhance teaching and learning.

- Evaluate learner outcomes and design strategies to improve classroom practice.

- Monitor the work of educators through scrutiny of work plans and learner outcomes.

Bush et al (2010) add that HoDs have clearly allocated curriculum responsibilities in all eight schools. This is often demanding for these middle managers, who are expected to cover several learning areas, some of which are not their own specialist subjects. They also experience conflict between their own teaching role and the limited time available to manage the work of educators

Hoadley et al's (2009: 385) research showed that curriculum management is more effectively managed where it is seen as a whole school responsibility and where instructional leadership is used. However, they note that the great disparity of leadership style, resourcing 
and management, and the delegation of curriculum matters to subject leaders, is hampering improvement:

'Successful leadership of curriculum and instruction involves the ability to oversee a wide range of functions, most of which do not relate directly to teaching and learning. Moreover ... the majority of principals saw curriculum coverage as the responsibility of senior managers, rather than themselves.'

\section{Distributed leadership}

Hoadley et al (2009: 377) are cautious about the applicability of distributed leadership in a culture where hierarchical structures have predominated, a point also made by Singh and Lokotsch (2005). Naicker and Mestry (2011), drawing on interviews and observation in three Soweto primary schools, and subsequently with 100 teachers from a range of schools (2014) make a similar point about how autocracy inhibits distributed leadership:

'This study indicates that leadership in the three Soweto primary schools is rooted in classical leadership practices and that a shift from autocratic styles of leadership, hierarchical structures and non-participative decision-making is needed if distributive leadership is to develop'. (Naicker and Mestry 2011: 12-13).

Williams (2011), and Mafora (2013) also argue that distributed leadership is difficult to implement in traditional hierarchical contexts and points to the dysfunctional and unintended consequences of the transformational agenda:

'The majority of South African schools function in contexts which are generally not conducive to distributed leadership. The transformation of the South African education system since 1994 has resulted in what one school principal referred to as "policy overload". In an effort to deal with the transformational initiative, educators have generally become strained and spent, and increasingly unmotivated and frustrated". (Williams 2011: 190).

\section{Teacher leadership}

Teacher leadership is one manifestation of distributed leadership (Bush 2011) but it is also growing in significance as a model in its own right. Grant (2006: 511) reports on a study in 
five KZN schools and notes that 'few teachers appear to be embracing a teacher leadership role'. She also echoes the negative impact of bureaucratic structures:

'The main barriers to teacher leadership that emerged in this initiative included hierarchical school organization controlled by autocratic principals, an understanding of leadership as linked to a formal position, as well as teachers who are initially resistant to change because of their lack of understanding of the complexity of the change process. These barriers are real and must be taken seriously in the quest for teacher leadership' (Ibid: 529)

Grant et al's (2010: 416) subsequent survey of 81 schools in KwaZulu-Natal led her to confirm her earlier view of the restricted nature of teacher leadership in many KwaZulu-Natal schools. Grant (2006: 529) adds that 'developing a culture of teacher leadership must be seen as an evolutionary process, underpinned by a new understanding of leadership.... Principals need to be supported as they learn to delegate authority and teachers need to be supported as they take up their leadership role '.

The discussion of transformational, instructional, distributed and teacher leadership shows that the introduction of these approaches to leadership is inhibited by entrenched managerial leadership. Academic discourse is changing but there is little evidence that these emerging models are widely practiced in South African schools.

\section{School Governance}

The introduction of school governing bodies from 1997 was widely regarded as an important aspect of grassroots democracy in the new South Africa. However, Xaba's (2011: 210) research shows the problems inherent in establishing effective governance:

'It is clear from the participants' responses that there are difficulties in understanding governance, mainly because governors perceive their roles differently, which detracts from their main responsibility - promoting the best interests of the school. This, combined with less than adequate capacity-building, as required by the Schools Act, adds to the ineffective execution of functions'.

Mestry and Khumalo (2012) examine governor involvement in relation to learner discipline, regarded as one of the most contentious issues, and stress the importance of developing a code of conduct for learners. They add that, despite the problems of illiteracy and lack of 
confidence, and the associated lack of knowledge of legislation, some schools are moving forward to develop, monitor and evaluate policies.

Mncube (2009: 102) conducted research with governors in four schools, leading to a survey of 430 parents in ten different schools, supplemented by observation of two SGB meetings. He concludes that, with the complexity of the legal framework, and the nature of the relationship between stakeholders, it is not surprising that the democratic voice of parents is barely heard in some schools.

'While representation and debate are theoretically open and fair, structural and behavioural factors still inhibit the extent to which SGBs operate; the authoritarianism of school leadership and governance, characteristic of the apartheid era, have disappeared, yet issues concerning values, behaviour, attitudes and skills necessary for full democratic participation remain'.

Mbokodi and Singh (2011) report on parental partnerships in the governance of five primary and five secondary schools in the townships close to Port Elizabeth where, although legal requirements are being met, parental involvement is ineffective because of problems arising from the poor education of those involved. Brown and Duku (2008), drawing on interviews with 48 parents in rural parts of the Eastern Cape, note the poor conceptions of governance and management in all component groups and report extensive use of micro-political groupings within the SGBs under review, the silencing of minority (usually female or younger men) members, and the gender related conflicts and tensions, where 'traditional' views of women are upheld by dominant males.

Clase et al (2007: 253) examined tensions between the SGB, and district or provincial authorities, based on surveys and interviews with 63 officials and 40 SGB groups in Afrikaans Free State schools, and conclude that, unless these can be resolved, there can be little hope for educational improvement. They argue that these tensions arise from different interpretations of the concepts of management and control, uncertainty regarding the purpose and responsibilities of the SGB, mutual mistrust and weak relationships.

Mabovula (2009: 219) focuses on the role of learners in school governance and notes that learner expression is guaranteed in the national Department of Education's guidelines for Representative Councils of Learners, as part of democratic governance. He concludes that the 'potential, limitations, constraints, consequences, and challenges facing learners in the school governance structure need to be revealed and debated'. Mathebula (2005: 190) 
comments that the role of representative councils is hampered by the minimal and traditionally authoritarian views of democracy evident in many schools. As noted above, Mncube (2008) also concluded that there is very limited involvement of learners in school governance, despite the national framework for their involvement.

To secure changes to increase learner participation will require modification of both principal and educator attitudes, especially in those areas where the culture is still 'elder' dominated, and where challenge in debate is seen as disrespectful.

Smit and Oosthuizen (2011: 64), drawing on a survey of 456 principals, SGB chairs and district officials, and on workshop discussions, also stress the importance of all stakeholders understanding the difference between participative democracy and political democracy and show that these concepts are frequently confused. They point out that the development of democratic principles in action may be inhibited by the political activity of educators, notably through teacher union activity.

\section{Accountability}

The emerging literature on governance (e.g. Mabovula 2009 and Xaba 2011) shows awareness of the ways in which accountability for provision, management and outcomes rests with SGBs as set out in the South African Schools Act (1996). Mestry (2004: 127-128) exemplifies this in the management of school finances. He notes the difference between the professional management functions of the principal, in managing finance and human resources, and the governance functions, including the preparation of budget, resourcing and financial evaluation of the school. He adds that:

'A problem with the delegation of duties from the SGB to the principal is that the principal is generally better informed with regard to the delegated tasks than the school governing body. The danger is that the principal may use this information to pursue his or her own objectives at the expense of the school. This implies that the principal is in the position of wielding power when the SGB are either illiterate or have little knowledge when dealing with school financial matters'.

\section{School Development}


School development is inevitably linked to changes in the wider political and social environment. Fleisch and Christie (2004: 95) note that:

'systemic school improvement, particularly for disadvantaged children, is inextricably linked to wider social, economic and political conditions-in South Africa's case, the political transition from apartheid to democratic government. These structural conditions and specific historical contexts are often glossed over in models of school effectiveness/improvement.'

They conclude that school improvement in South Africa links to the centrality of structural contexts - political, economic and socio-cultural - that are experienced as school-level effects.

\section{School development planning}

School development planning was introduced in the UK in the 1990s and subsequently encouraged in South Africa, an example of policy borrowing. Xaba (2006: 24) analysed the situation when schools were being required to develop plans in Gauteng and concluded that:

'Schools find it difficult to engage in the process because they are "merely" fulfilling an externally identified need. Consequently, schools struggle to find areas needing improvement. Development planning tends to yield superficial and unrealistic targets. This happens at the expense of the need for real innovation and change at schools'.

Xaba (2006: 24) argues that development planning should be the responsibility of school management teams (SMTs) and cautions that 'planning should not be for the purpose of submission to the department'. He suggests that, for school development planning to be successful, the following points should be considered:

- The school principal and SMT should be charged with the responsibility of ensuring the initiation of development planning, as well as its implementation.

- Instead of seeming to "force" change and innovation, the school development planning process should have learning as its starting point so as to ensure that school development planning objectives and activities are focused on the achievement of learning. 
He concludes that, by adopting these principles, 'schools will be in a position to self-audit in a realistic manner which focuses on schools' own improvement, innovation and change needs (Ibid: 24). He was able to provide empirical evidence from two schools where the planning process was seen to be effective:

- The whole process opened avenues for a climate of teamwork between parents, governors and staff, general and administrative staff, including support staff.

- The process enabled staff to deal openly with issues relating to interpersonal relationships. The team spirit that prevailed during and after the planning process, helping to overcome the previous limited teamwork in these schools.

- School governors realised, through the process, the importance of their roles and responsibilities in promoting the interests of the school. This highlighted the need for training of SGB members in school governance and was included in the SDP as a challenge that needed to be addressed.

- The process induced everyone to realise the state of the schools' external environment. The issues of poverty and parent illiteracy were unpacked and understood in the context of parental and community involvement in the school. As a result, the need for home visits was identified and included as an aspect of the school's long-term plans.' (Ibid: 23).

While Xaba's (2006) research appears to paint a positive picture, there is little evidence of widespread development planning. Steyn and Wolhuter (2010: 456), and Boateng (2014) argue that there has been little improvement in schools' capacity to engage in planning because many schools, and some districts, in South Africa are dysfunctional, or do not function optimally.

\section{Leading and Managing People}

Leading and managing people are central aspects of school leadership in all contexts (Bush and Middlewood 2013) but may be of particular significance in South Africa. In this section, we review the literature on this theme.

\section{Staff development and mentoring}

The emerging research on staff development is concerned with teacher perceptions of the context within which they work and leadership plays a large part in determining this context. Bantwini (2012: 517) explains how this affects teacher quality through professional development in primary schools in the Eastern Cape: 
'Teachers had negative perceptions that led to the belief that they were not receiving the support and tools they needed for professional development from their district. The impact of their perceptions was evident in the slow or non-implementation of the district's newly launched curriculum reforms . . . Failure to address teachers' perceptions is likely to result in teachers not benefiting from their professional development programs'.

Luneta's (2012: 377) literature review on teacher attitudes to further training also concludes that educator involvement in planning activities assists a more positive attitude. Moorosi (2012: 501) draws upon the data sets from two investigations to consider the impact of mentoring as a means of leadership development. She differentiates between the groups of people providing the mentoring and the context within which the process takes place. She links mentoring to several aspects of diversity within South Africa:

'Although the majority of mentors were male and protégés were female, gender alone does not appear to have jeopardized these mentoring relationships. Instead, more protégés benefited from cross-gendered relationships. However, the racial composition of mentors seems to have had some influence on mentoring. Same-race relationships appear to have worked better than cross-race ones and more disadvantage was experienced where there were two or more levels of diversity'.

Mestry et al (2009: 480) stress the links between effective professional development and teacher motivation. 'For professional development to be effective, motivation should be intrinsic rather than extrinsic'.

\section{Performance management}

The under-performance of South African schools (see above) has led to attempts to manage the performance of educators. The most prominent, and enduring, model is the Integrated Quality Management system (IQMS). De Clerq (2008: 9) comments on the IQMS approach and its impact on teacher development:

IQMS makes problematic assumptions about educator quality and improvement in South African schools. It is not aligned with the status and work of most educators, and over-estimates the implementation readiness of the majority of schools as well as the appraisal and support capacity of senior school and district management. The 
challenge is to make educators behave and be treated as professionals, as well as to manage the inevitable tensions of appraisal systems'.

De Clerq (2008) concludes that a systemic approach to teacher monitoring and development is not sufficient because it also requires changes in the beliefs and attitudes of educators and appraisers. For appraisal to be effective, it is necessary to develop support systems to foster development.

Queen-Mary and Mtapuri (2014) conducted open-ended interviews with various stakeholders and conclude that the IQMS was implemented too readily. They posit an alternative, bottom up, model, focused on educator development informed by participation and empowerment. Mosoge and Pilane (2014), drawing on interviews with 15 participants, also claim that development has been neglected within IQMS, in favour of appraisal linked to incentives.

\section{Leadership teams}

Bush et al (2010) found several examples of dysfunctional senior management teams (SMT) in their small-scale study in Limpopo and Mpumalanga. However, Bush and Glover's (2013) survey of 180 Mpumalanga SMT members showed that the framework for greater team effectiveness was in place in many schools with almost a third meeting weekly and the great majority (88\%) meeting at least monthly. There was also an enhanced focus on instructional leadership, with more than half of respondents including curriculum management, and monitoring teaching and learning, among their top two priorities. However, Hoadley et al's (2009) research in the Eastern and Western Capes found that the priority role of the principal is that of school administration, thus minimising the leadership function of SMTs.

\section{Teacher unions}

There is widespread anecdotal evidence that teacher unions contribute to underperformance in South African schools by adopting a negative approach to initiatives intended to promote improvement. Msila's (2014) study of ten urban schools in the Eastern Cape suggests that strong union affiliations lead to the 'paralysis' of school management and leadership, with negative consequences for teaching and learning.

\section{Leadership development}


Since the introduction of the ACE: School Leadership programme there has been growing awareness that the functions of leadership should be exercised by a wider range of people within schools. In their review of the programme, Bush et al (2011: 39) conclude that:

'The flexibility and initiative required to lead and manage schools in periods of rapid change suggest that preparation should go beyond training principals to implement the requirements of the hierarchy to developing rounded and confident leaders who are able to engage all school stakeholders in the process of school improvement for the benefit of learners and their communities.'

Leadership development is fundamental to change but R. Botha (2011) is critical of the leadership style of authoritarian principals, as a limiting factor in leadership development, and notes the overwhelming need for enhanced professionalism for principals. E. Botha (2012: 406) suggests than one approach might be to create professional learning communities which consider change through talking, asking relevant questions, and making decisions together.

Mentoring for leadership development has been investigated by Msila (2011: 51) who, following in depth observation of 12 mentors and their mentees, notes that:

'The mentors and their mentees had a huge role to play in the process; the personalities of the individuals involved were very crucial in their relationship . . . Change agents for both mentors and mentees learn easily and are open to ideas different from their own. In a mentoring relationship, this proves very important because one listens and understands because they have embraced change'.

Msila (2011) also points to the need for mentors to be effective in all aspects of their leadership practice and that the development of this approach is dependent upon the availability of trained and respected mentors.

\section{Managing Physical and Financial Resources}

Physical and financial resources provide much of the support required to implement the management of teaching and learning in South Africa (Bush and Heystek 2006). However, there is only limited research on these management issues.

\section{Managing finance}


Bush and Heystek's (2006) survey of Gauteng principals showed that they regarded financial management as their main development need. Mestry and Holongwane (2009: 341) add that principals feel that financial management is more complex when involving SGB members, as required by the legal framework.

Hoadley et al (2009: 374) stress the importance of the resource base for educational improvement, and the significance of the local context. Their evidence demonstrates the continuing disparity in resources available to schools in different contexts:

'New funding arrangements allowed for fees to be levied, introducing a quasi-market into schooling, and at the same time provision was made for a measure of funding redistribution in favour of poor schools... The new policies, designed to change the system from top to bottom, . . . did not speak to the conditions of the majority of schools, or adequately address the deep historical inequalities and uneven quality that existed within and across the country's schools. The best functioning schools in the system were able to use the new management dispensation to raise fees, employ 'governing body' teachers, provide salary supplements, and offer a broad curriculum with specialist support. Not so the majority of schools in the system, often in communities too poor to pay fees, without capable governing bodies, without libraries, laboratories and computer networks to support the new curriculum and often with demotivated teachers'.

There is limited research about the way in which individual schools make use of financial planning, resource management, and the monitoring and evaluation of funds. However, Mestry (2004: 127), following focus group interviews and observations with SGB members and educators in four schools south of Johannesburg, concludes that there were four main problems at that time. First, in some schools, the principal and the school governing bodies did not work collaboratively with each other in managing the schools' finances. Second, the SGBs were not trained effectively to manage the school's finances. Third, some of the principals objected to the cascading model of training and found the content of the workshops to be too theoretical. Fourth, the Department of Education had no mechanisms in place to support schools on financial issues and problems.

These findings are similar to those of Mestry and Hlongwane (2009: 333), who investigated the perceptions of 20 secondary school governors in Gauteng and noted that problems arose from the lack of financial resources, the imperfections of cascading training, variations 
in the frequency and attendance at training sessions, the quality of training on offer, and a general apathy amongst SGB members. They concluded that:

'Schools should take the initiative of planning ongoing SGB training as well as provide induction programmes for new parent governors elected or co-opted to SGBs, even though it is the PED's responsibility' (Ibid: 337).

Lekalakala (2009) found similar problems with either lack of training opportunities, or lack of quality provision, in the Ramotse area of Tshwane, Gauteng. In an attempt to help develop policy, and to clarify the complexity of financial management, Van Rooyen (2012) outlines current research and provides guidelines for financial management at all levels. Thenga's (2012) study of practice in Gauteng township schools shows a lack of SGB training, inconsistent training, lack of accounting skills, and differing practice by local district education officials.

\section{Managing health and safety}

There is only limited research on this aspect of school management. Barnes et al (2012: 80) examined the relationship between school culture and violence in the Eastern Cape, and stressed the importance of developing clear policies, of securing educator support for learners in difficulty, and of involving learners in violence management. Singh and Surujlal (2010: 118), drawing on interviews in 12 schools, discuss the role of educators in managing risk and conclude that 'educators are not adequately aware of, or do not fully comprehend, the implications of their legal liability relative to activities in PE at schools'.

\section{Managing school grounds, buildings and equipment}

Xaba (2012: 221), following research into attitudes and practice in 12 Gauteng primary and secondary schools, discusses the responsibility of governors, principals and educators in providing safe opportunities for all school activities. He distinguishes between five aspects of maintenance; organisation, inspection, planning, policies, and funding. He notes that, without policy directives informing school facilities management and maintenance, schools would not have systematic processes aimed at ensuring that school facilities maintenance promoted educational programmes. He comments that participants generally did not have knowledge of school facilities maintenance and concludes that facilities maintenance at schools, and possibly at departmental level, is not accorded a priority status. He advocates governor training to ease the burden of facilities management for the principal and senior 
staff and suggests the establishment of facilities maintenance committees, drawing upon community expertise.

\section{Managing Teaching and Learning}

Bush and Heystek (2006) note the low priority given to this activity by Gauteng principals but there has been some change in attitudes since then, partly prompted by the inclusion of MTL as a core module in the ACE: School Leadership programme. In this section, we review the research on different aspects of MTL.

\section{Curriculum management}

Most of the research on this theme relates to the macro level of curriculum management, rather than to classroom practice. Ngidi and Qwabe (2006: 530) offer a list of 31 factors which may affect curriculum effectiveness and urge a productive integration of educators, learners, and parents, in curriculum design and implementation, aiming at developing a culture of teaching and learning. Hoadley et al (2009: 386) show how curriculum management in 200 schools was affected by the social context of the school, the nature of school culture, so that it is 'learning centred', relationships between schools and homes, good use of resources, and the extent of leadership dispersal within the school:

'The findings of this research point to the importance of parental support and engagement as well as the instructional focus of the school in achieving student gains over time. The research largely confirms what we do know about school management in South Africa, and aligns with much of the findings of the international research base'.

Drawing on their empirical study of 146 schools in the Eastern and Western Capes, Hoadley et al (2009: 383) add that the school curriculum should be fully covered, with a well worked out plan to improve student results, and making the fullest use of the day for maximum learning. This requires a stress on learning, a positive culture, positive home-school relationships, good resource management, and effective distributed leadership as well as an instructional focus.

For Steyn and Wolhuter (2010: 456), curriculum management stems from the link between strategic planning at provincial, district and school levels so that the problems of failure, dropout, educator and learner absenteeism, and indiscipline, can be overcome before the 
content is planned. Lumadi (2012: 121) comments that this is a topic 'driving the school management team frantic' in Mpumalanga:

'The SMT is responsible for planning, and directing the work of a group of teachers and students, monitoring their work, and taking corrective action where necessary. They have the authority to change the work assignments of team members. As with many institutions, the leadership of secondary schools in Mpumalanga involves the evolution of a shared vision through effective strategies that allow that vision to be realised. This involves putting all available resources to work in the most effective way to ensure that the best standard of education for all students is provided.' (Ibid: 122).

Lumadi (2012: 134) adds that the:

'principal is the instructional leader, which implies that he (sic) must know about curriculum change ... Moreover, the SMT members are ... the custodians of the quality of teaching and learning in their respective schools.'

\section{Evaluating learner outcomes}

Evaluation is concerned with analysing school data for strategic purposes. Bush and Glover (2009) suggest that this would require schools to:

- Provide a systematic review of performance across learning areas, with an honest appraisal of the reasons for perceived under-performance. These reasons should go beyond 'blame the learner' responses to a careful assessment of how educators and school managers can work towards improved outcomes.

- Devise context-based strategies to enhance learner outcomes. These might include professional development for educators, modelling of good practice by effective teachers, and monitoring the performance of less effective educators.

- Address within-school variation by asking more successful educators and managers to mentor those who are less successful.

Rampa (2010: 206) conducted qualitative and quantitative research in 14 schools in Tshwane, Gauteng, and concludes that: 
'The principals indicated that the leadership at their schools was weak. They found themselves alone in the centre, and felt challenged by the unions and the lack of support from the communities. Although objectives were set during strategic planning, nothing was achieved in terms of implementation and evaluation'.

Bush et al (2010) show that the difference between evaluation and monitoring is not fully understood and, although seven of the eight schools they studied in Limpopo and Mpumalanga used in-school assessments as the basis of educator assessment, there was variation in the way in which evidence was collected and used. Within school variation focuses on the results from the same cohort in different subject areas and points to the need for open discussion of laziness, blame cultures, inconsistency, and unwillingness to learn from colleagues. They argue that observation of classroom practice is fundamental to improvement.

\section{Monitoring classroom practice}

Monitoring classroom practice is linked to attempts to improve examination results. Mji and Makgato (2006: 253) examined the same subjects in seven poorly performing schools, and pointed out that learner achievement is directly influenced by teaching strategies, content knowledge, motivation, laboratory use, and non-completion of the syllabus in a year.

\section{Classroom observation}

Hariparisad et al (2006) state that observation is formative, to enhance teaching skills, and summative, to provide a basis for grading and promotion. Bush and Glover (2009: 5) see the need for observation to be embedded in schools.

'This is likely to require a paradigm shift in many schools, prompted by firm but supportive leadership. One way for principals to encourage acceptance of observation is to invite educators to observe their own teaching, a form of reflective practice, and to provide feedback. Some principals may lack the confidence to do this, but it does provide the potential to 'model' good classroom practice'.

\section{Mentoring}

Following classroom observation, development needs for educators may be identified and mentoring is widely regarded as an important process for addressing such needs. However, there is very limited research on this activity in South African schools although Moorosi 
(2012) and Msila (2011) have examined the role of mentoring in developing school principals (see above).

Modelling

Leithwood (1994) includes 'modelling best practices' among his eight dimensions of transformational leadership. Although educators may be mentored, this is of limited value if they are not able to see good practice in schools and classrooms. Bush (2013) notes that evidence of modelling is very limited in South Africa but he adds that modelling good practice by the principal, a head of department, or another educator, may well be advantageous as an aspect of MTL. Nieman and Kotze's (2006: 614) survey of 30 school staff in the Free State identified five leadership qualities, including 'modelling the way'.

\section{Conclusion}

This literature review was commissioned to inform the planning of a new Advanced Diploma in Education (School Management), a national qualification for current and aspiring school principals. The previous review (author and author 2007) provided the starting point for its predecessor course, the Advanced Certificate in Education (School Leadership), which was made mandatory for all new principals by the Council of Education Ministers in 2011 . The review offers a comprehensive review of the South African literature on school leadership and management, structured to match the framework of the ACE programme, to inform programme design and content. It is believed to be the only systematic review of this body of literature since 2007, and should be an important resource for scholars, policy-makers and practitioners.

This review shows that, while empirical evidence has been growing since 2007, it remains inadequate to draw firm conclusions about many aspects of school leadership and management in South Africa. Some topics still have limited research, notably managing physical and financial resources, and managing teaching and learning. In other areas, there is more relevant literature but some of this is normative and even empirical sources are often based on small-scale projects, for example from a very limited number of case studies. More substantial research is required on many topics, including school governance, site management, financial management, managing people, and instructional leadership. In particular, more evidence is required to answer the key research question; why do most South African schools continue to under-perform? 


\section{References}

Ali, F. and Botha, N. (2006), Evaluating the Role, Importance and Effectiveness of Heads of Department in Contributing to School Improvement in Public Secondary Schools in Gauteng, Johannesburg, MGSLG

Author and Author (2007), Literature Search for the Zenex ACE School Leadership: Second Interim Report, Pretoria, Department of Education

Bantwini (2010), How teachers perceive the new curriculum reform: Lessons from a school district in the Eastern Cape Province, South Africa, International Journal of Educational Development, 30 (1): 83-90

Barnes, K., Brynard, S. and de Wet, C. (2012), The influence of school culture and school climate on violence in schools of the Eastern Cape Province, South African Journal of Education, 32 (1): 69-82

Boateng, N. (2014), Technical efficiency and primary education in South Africa: evidence from subnational level analyses, South African Journal of Education, 34 (2): 1-17.

Botha, E.M. (2012), Turning the tide: creating professional learning communities (PLC) to improve teaching practice and learning in South African public schools, Africa Education Review, 9 (2): 395411

Botha, R.J. (2011), The managerial role of the principal in promoting teacher professionalism in selected Eastern Cape schools, Africa Education Review, 8 (3): 397-415

Bray, R. and Moses, S. (2011), Children's participation in South Africa: Exploring the landscape, Perspectives in Education, 29 (1): 6-17

Brown, B.A. and Duku, N. (2008), Negotiated identities: dynamics in parents' participation in school governance in rural Eastern Cape schools and implications for school leadership, South African Journal of Education, 28 (3): 431-450

Bush, T. (2007), Educational leadership and management: Theory, policy and practice, South African Journal of Education, 27 (3): 391-406

Bush, T. (2011), Theories of Educational Leadership and Management: Fourth Edition, London, Sage

Bush, T. (2013), Instructional leadership and leadership for learning, Education as Change, 17 (S1), 5-20.

Bush, T. and Glover, D. (2009), Managing Teaching and Learning: A Concept Paper, Johannesburg, MGSLG

Bush, T. and Glover, D. (2012), Leadership development and learner outcomes: Evidence from South Africa, Journal of Educational Leadership, Policy and Practice, 27 (2): 3-15

Bush, T. and Glover, D. (2013), School management teams in South Africa: A survey of school leaders in the Mpumalanga province, International Studies in Educational Administration, 41 (1): 2140

Bush, T. and Heystek, J. (2006), School leadership and management in South Africa: Principals' perceptions, International Studies in Educational Administration, 34 (3): 63-76

Bush, T., Joubert, R., Kiggundu, E. and van Rooyen, J. (2010), Managing teaching and learning in South African schools, International Journal of Educational Development, 30(2), 162-168 
Bush, T., Kiggundu, E. and Moorosi, P. (2011), Preparing new principals in South Africa: the ACE: School Leadership Programme, South African Journal of Education, 31 (1): 31-43

Christie, P., Butler, D. and Potterton, M. (2007), Schools that Work: Report of Ministerial Committee, Pretoria, Government Printer

Clase, P., Kok, J. and van der Merwe, M. (2007), Tension between school governing bodies and education authorities in South Africa and proposed resolutions thereof, South African Journal of Education, 27 (2)

De Clercq, F. (2008), Teacher quality, appraisal and development: The flaws in the IQMS, Perspectives in Education, 26 (1): 9-13

Fleisch, B. and Christie, P. (2004), Structural change, leadership and school effectiveness /improvement: Perspectives from South Africa, Discourse: Studies in the Cultural Politics of Education, 25 (1)

Grant, C. (2006), Emerging voices on teacher leadership Some South African views, Educational Management, Administration and Leadership, 34 (4): 511-532

Grant C., Gardner K., Kajee F., Moodley R. and Somaroo, S. (2010), Teacher leadership: a survey analysis of KwaZulu-Natal teachers' perceptions, South African Journal of Education, 30 (3): 401-419

Hariparsad, I., Bisschoff, T., Conley, L., du Plessis, P., Grobler, B., Hlongwane, S., Loock, C. and Mestry, R. (2006), Quality Assurance in South African schools: An Integrated Research Report, CCEAM Conference, Cyprus, October

Hoadley, U., Christie, P. and Ward, C.L. (2009), Managing to learn: instructional leadership in South African secondary schools, School Leadership \& Management, 29 (4): 373-389

Jacobs, L. (2014), Framing of school violence in the South African printed media - (mis)information to the public, South African Journal of Education, 34 (1): 1-14.

Jansen, J.D. (2005), Targeting education: The politics of performance and the prospects of 'Education for All', International Journal of Educational Development, 25 (4): 368-380

Kamper, G. (2008), A profile of effective leadership in some South African high-poverty schools, South African Journal of Education, 28 (1): 1-18

Kanjee A. and Prinsloo, C. (2005), Improving Learning in South African Primary Schools: The Quality Learning Project, Pretoria, HSRC

Leithwood, K. (1994), Leadership for school restructuring, Educational Administration Quarterly, 30 (4): $498-518$

Lekalakala, M.T. (2009), Problems Encountered by School Governing Bodies in Executing their Financial Tasks, Unpublished thesis, UNISA

Lumadi, M.W. (2012), Curriculum management: 'driving the school management team frantic', Africa Education Review 9 (1): 121-135

Luneta, K. (2012), Designing continuous professional development programmes for teachers: A literature review, Africa Education Review 9 (2): 360-379

Mabovula, N. (2009), Giving voice to the voiceless through deliberative democratic school governance, South African Journal of Education, 29 (2): 219-233

Mafora, P. (2013), Learners' and teachers' perceptions of principals' leadership in Soweto secondary schools: a social justice analysis, South African Journal of Education, 33 (3): 1-18 
Mathebula, T. (2005), The role of Representative Councils for Learners in South African schools: Maximal or minimal participation? Africa Education Review, 2 (2): 189-204

Mbokodi, S.M. and Singh, P. (2011), Parental partnerships in the governance of schools in the Black townships of Port Elizabeth, South African Journal of Education, 29 (4)

Mestry R (2004), Financial accountability: The principal or school governing body? South African Journal of Education, 26 )1): 27-38

Mestry, R. and Hlongwane, S. (2009), Perspectives on the training of school governing bodies: towards an effective and efficient financial management system, Africa Education Review, 6 (2): 324342

Mestry, R. and Khumalo, J. (2012), Governing bodies and learner discipline: managing rural schools in South Africa through a code of conduct, South African Journal of Education, 32 (1): 97-110

Mestry, R, Hendricks, I and Bisschoff, T. (2009), Perceptions of teachers on the benefits of teacher development programmes, South African Journal of Education, 29 (4): 475-490

Mji, A. and Makgato, M. (2006), Factors associated with high school learners' poor performance: a spotlight on mathematics and physical science, South African Journal of Education, 26 (2)

Mncube, V. (2009), The perceptions of parents of their role in the democratic governance of schools in South Africa: Are they on board? South African Journal of Education, 29 (1): 83-103

Moorosi P. (2010), South African females career paths: understanding the gender gap in secondary school management, Educational Management, Administration and Leadership, 38 (5): 547-562

Moorosi, P. (2012), Mentoring for school leadership in South Africa, Professional Development in Education, 38 (3): 487-503

Mosoge, M. and Pilane, M. (2014), Performance management: the neglected imperative of accountability systems in education, South African Journal of Education, 34 (1): 1-18.

Msila, V. (2011), School management and the struggle for effective schools, Africa Education Review, 8 (3): 434-449

Msila, V. (2014), Teacher unionism and school management: a study of (Eastern Cape) schools in South Africa, Educational Management, Administration and Leadership, 42 (2): 259-274.

Naicker, S.R. and Mestry, R. (2011), Distributive leadership in public schools: Experiences and perceptions of teachers in the Soweto region, Perspectives in Education, 29 (4)

Naicker, S.R. and Mestry, R. (2014), Teachers' reflections on distributive leadership in public primary schools in Soweto, South African Journal of Education, 33 (2): 1-18.

Ngcobo, T. and Tikly, L.P. (2008), Think Globally, Act Locally: A Challenge to Education Leaders, Paper presented to the CCEAM Conference, September, Durban

Ngcobo, T. and Tikly, L.P. (2010), Key dimensions of effective leadership for change: A focus on township and rural schools in South Africa, Educational Management, Administration and Leadership, 38 (2): 202-228

Ngidi, D. and Qwabe, J. (2006), The partnership of parents, educators and principles in creating a culture of teaching and learning in schools, South African Journal of Education, 26 (4): 529-539 
Nieman, R. and Kotze, T. (2006), The relationship between leadership practices and organisational culture: an education management perspective, South African Journal of Education, 26 (4): 609624

Queen-Mary, T. and Mtapuri, M. (2014), Teachers' perceptions of the Integrated Quality Management System: lessons from Mpumalanga, South Africa, South African Journal of Education, 34 (1): 1-17

Rampa, S.H., (2010), A customised total quality management framework for schools, Africa Education Review, 7 (1): 199-217

Singh, P. and Lokotsch, K (2005), Effects of transformational leadership on human resource management in primary schools, South African Journal of Education, 25 (2): 279-286

Singh, C. and Surujlal, J. (2010), Risk management practices of high school sport coaches and administrators, South African Journal for Research in Sport, Physical Education and Recreation, 32 (1)

Smit, M. and Oosthuizen, I. (2011), Improving school governance through participative democracy and the law, South African Journal of Education, 31 (1): 55-73

Soudien, C. (2007), The 'A' factor: coming to terms with the question of legacy in South African education, International Journal of Educational Development, 27 (2):182-193

Steyn, G.M. (2013), Interpreting the leadership practice of a South African school using the leadership practice model, New Generation Sciences, 1 (1): 104-116

Steyn, H. and Wolhuter, C. (2010), Creating sustainable learning environments in schools by means of strategic planning: The experience of engagement by a comparative education team at a university, South African Journal of Higher Education, 24 (3): 456-470

Thenga, C.M. (2012), Managing School Funds in selected secondary schools in Gauteng province, Unpublished thesis, UNISA

van Rooyen, J. (2012), The Relationship between Funding in Education and Quality Education, Unpublished Ph.D. thesis, University of Pretoria

van der Westhuizen, P. and van Vuuren, H. (2007), Professionalising principalship in South Africa, South African Journal of Education, 27 (3): 431-445

Villiers,E. and Pretorius, S.G. (2011), Democracy in schools: are educators ready for teacher leadership? South African Journal of Education, 31 (4): 574-589

Vos, D., van der Westhuizen, P.C., Mentz, P.J. and Ellis, S.M. (2012), Educators and the quality of their work environment: an analysis of the organisational climate in primary schools, South African Journal of Education, 32 (1) 56-68

Vos, D., Ellis, S.M., van der Westhuizen, P.C., and Mentz, P.J. (2013), Applicability of the Organisational Climate Description Questionnaire - Rutgers elementary, South African Journal of Education, 33 (3), 1-17

Weeks, F., (2012), The quest for a culture of learning: a South African schools perspective, South African Journal of Education, 32 (1): 1-14

Williams, C.G. (2011), Distributed leadership in South African schools: possibilities and constraints, South African Journal of Education, 31 (2): 190-200

Wolhuter, C. (2014), Weaknesses of South African education in the mirror image of international educational development, South African Journal of Education, 34 (2): 1-18 
Xaba, M. (2006), An investigation into the basic safety and security status of schools' physical environments, South African Journal of Education, 26 (4): 565-580

Xaba, M. (2011), The possible cause of school governance challenges in South Africa, South African Journal of Education, 31 (2): 201-211

Xaba, M. (2012), A qualitative analysis of facilities maintenance -- a school governance function in South Africa, South African Journal of Education, 32 (2): 215-226

Zulu, S., (2004), The instructional role of school principals, Unpublished Ph.D. thesis, UNISA 